\title{
FROM BENEDITO'S RED TO SEBASTIÃO'S BLUE: making festival and attractiveness of Marujada in the Brazilian Amazon
}

\author{
Maria Augusta Freitas Costa Canala \\ Hygo da Silva Palhetab \\ Milene de Cássia Santos de Castro ${ }^{c}$
}

\begin{abstract}
The attractiveness from events based on sociocultural valorization foments the tourist destination. Thus, this work seeks to analyze the act of making festivals and the attractiveness of Marujada in the Brazilian Amazon in Tracuateua city. The analysis procedures involved the research in a qualitative way, through the survey of documentary and bibliographic data, with fieldwork including semi-structured interviews and field notes with guided observation script and semi-structured interview conducted with 12 organizers and makers of Tracuateua'sMarujada festival. The results demonstrate that the act of making festivals allows the fraternization of frequenters, through the act of partying, and the attractiveness provided by Marujada can attract tourist flows. In addition to encouraging the culture of the microregion of Bragança and strengthening the festival. It is considered that the Marujada party contributes positively to the safeguard of local culture.
\end{abstract}

\section{Keywords:}

Party

Touristic Attraction

Tourism 


\section{INTRODUCTION}

The city of Tracuateua was a village in Bragança city, in Pará, until 1994 when it became politically autonomous; its name was derived from the designation "Tracuá", a local species of black ant, and "teua" (Pinheiro, 2017). This city is located approximately 180 kilometers from the capital (Belém), and it is in the northeastern mesoregion of the state of Pará and in the Bragantine microregion (Pará, 2014). In this way, in Tracuateua, the Marujada party has been held since 1947 in January in reverence to two saints of the Catholic Church: Saint Benedict, the devout saint of Marujada, and Saint Sebastian, the patron saint of the place. In this sense, an analysis of the festive space-time of Tracuateua's Marujada, which is intended to present in this work translates a part; of data and the elaboration of a four-year institutionalized research project and outlines its problematic through the following questions: how is it configured, what are the meanings of festive activities experienced by the makers of Marujada festival in the festive space-time of Tracuateua and its implications to tourist attractiveness? Thus, it is aimed to identify and analyze how the experiences of party makers in the space-time of Marujada allow us to understand the relationship between image and tourist attraction from what they want to enunciate in their social experience.

According to Sollerio \& García (2020), the treatment of the tourist space as supply and demand does not allow for more precise analyzes nor for more diverse and communicational production through multiple meanings and encounters with others, which leads us to consider the space of the attraction as imbricated in the relationships of the transfer, modification, and social experiences (Soja, 1993). In this sense, in the touristic space, the temporal procedural demarcates the experiences of the people who make the culture of the "receiving place", which presupposes understanding what this doing wants to communicate and enunciate itself from the social experience. This experience is not crystallized, as indicated by Filippim and Bahl (2017), it is impregnated by transformation-resignification that has in tourism a possibility of keeping the social practices. As Wagner (1981) states, culture is produced by the invention engendered by reproduction-repetition that, in some context and under determined perspective, erupts into innovation, therefore, into an invention between past-

${ }^{1}$ BGE Automatic Recovery System - SIDRA. Recovered from (https:// sidra.ibge.gov.br/home/pimpfbr/brasil) present-future.

The cultural appears in tourism as a specific segment or as a premise of diversification; however, sometimes it is in the supply-demand model. In this sense, the party, and the act of making festival are correlated to the cultural tourist process, which indicates the use and spatial-temporal appropriation of partying being outlined as an organization of a given materiality as mere distribution of objects and flows without interface of form-spatial content (Santos, 1999). According to Ferretti (2007) and Bueno (2008), the festival is presented by the act of making festival, which is derived from the participation in the ceremony and celebration of the party. According to Caillois (1988) and Claval (2011), the celebration and the festive ceremonial conform to a temporal experience in which the space of organization and participation is mixed with the experience of moments of origin and the mixture and participation among groups, peoples, populations etc. The way of making and experiencing the party configures a peculiar reality, turning the time-space of celebration into a unique festive activity that makes possible to think of a potential tourist attraction of the cultural encounter strengthened in the place.

In the tourist activity logic, parties conform as event that constitutes the precise demarcation of an event with well-defined and temporally circumscribed theme, from which it becomes a business multiplier phenomenon, having the potential to generate new flows of visitors capable of altering certain social dynamics (Bahl, 2004). In the tourist products configuration, events are essential and, although to a large extent they are linked to the calendar and tourist image aspects as scenarios to illustrate market requirements. They appear with more relevant dimension when projecting the local knowledge content value, entertainment, leisure, rest, abstractions, and imagination provided by the management of high culture and popular culture (Bahl, 2004; Espeso-Molinero, 2019).

To Bahl (2004), regarding the dimension of tourist attractiveness, events could not be alien to the social reality that surrounds them and, therefore, stimulating the need to restore local culture, foster self-esteem and value habits and traditional customs. In this sense, the parties stand out in the selective events and tourist calendars, like the Amazonian festivals in the formulation of the tourism product of Pará (Pará, 2011). In parallel, Berselli \& Zucco (2019) assess that the participation and involvement of locals is fundamental to sustain the success of an event. And they emphasize that the act of making events must be based on the residents' perception of the event and not just to attract tourists.

In the Brazilian Amazon, Marujada festival appears in the structure of touristic demand and supply in Pará as part of the state touristic calendar, receiving municipal and regional flows, and appears as an attractiveness of 
the city of Bragança, center of the Atlantic Amazon Tourism Pole, which has 45 municipalities, among them the Tracuateua city, which has in the Belém-Bragança Tourist Route (around an extinct railroad from the rubber period) an attempt of integration, density and consolidation of the tourist product in this hub. As an Amazonian cultural attraction, Marujada festival appears annually as a festival of São Benedito, which held in December on the streets along the waterfront and historic center of Bragança city, which crystallizes as a tourist offer in the communication and enunciation of this space-time. However, at the Atlantic Amazon Tourism Pole, this festive activity spreads to other towns in this micro-region, such as: Tracuateua, Augusto Corrêa, Vila Fátima and Quatipuru (Pinheiro, 2017).

\section{METHODOLOGY}

This research took place through an exploratory and descriptive study with qualitative analysis, which field work including semi-structured interviews and field notes (Cruz Neto,1994; Minayo, 2002), directed observation (Deslandes, 1994; Raffestin, 2009) with data analysis performed in categories demonstrated through tables organized in similar contents (Gomes, 1994). Consequently, from the interview applications the informants' reports are used, such verbal data are classified in this article and based on qualitative analysis as verbal information.

The fieldwork happened in two stages: the 1st) held in Tracuateua in July 2018, in January 2019 and in December 2019 in Bragança with the survey of guided observation with a propositional framework for recognition of spaces intended forma king festival considering environmental-physical-natural and sociocultural as well as mediators opened and free field notes. The 2 nd:was held in Tracuateua between September and October 2018.Consider the interviewees availability due to being long interviews and having the sample randomly defined among the 12 organizers and makers of the Tracuateua's Marujada party.

\section{CONSTRUCTION OF THE TRACUATEUA'S MARUJADA FESTIVE SPACE-TIME}

Party and celebration are expressed by a determined space-time which is defined by Caillois (1988) and Claval (2011); the daily life rupture goes back and returns to routine, in a word, the party model implies a spatial content of transgression by the exaggeration of the routine proceeding, highlighting aspects of daily life that one wants to celebrate and the culture that one wants to exalt. That is why, based on Claval (2011) and Da Matta (1997), to consider that celebrating is the escape from daily life for the exaltation of everyday life, an opportunity found by human beings to feel alive in the environment in which they live in the existential work of their free time in which "in a solidary coexistence, in different ways of being and living; men create, imagine and invent ways to support the human in the social way" (Bueno, 2008, p. 6). Therefore, the festival is an event that is experienced throughout the year by whoever makes the party and begins to think about it immediately after the end of its periods; by the social ties and solidarities engendered in the production of everyday life through the social group's participation in the festive space-time. Thus, the party space-time allows the touristic process for cultural production as well as diversification of attractiveness through the appreciation of the form-content of the local daily life experienced by the participation of making festival. Da Matta (1997), considering the festival in the enthusiasm and purpose of organizing and planning the party. According to the author, the planning and execution of spacetime does not express fatigue or/and limits for the people who organize the party; but there is the collective mood of the duty-satisfaction for the accomplishment of the festival, which is expressed by the collective desire to make the improvement every year, resulting in the collectivity that is dedicated to make the festival. This collective desire provides the party to have an aggregation of elements that are brought into the ceremonial and the joy of the festival that gives meaning to its existence and permanence. In other words, the party lives because there is the desire to celebrate.

Thus, the parties have cultural aspects and wealth in their way of celebrating, such as: colors, objects, songs, dances, food, and costumes that have their own meanings that can make the party peculiar in the exaltation of everyday perceptions experienced as disruptions of routine having multiple meanings that, according to Ferretti (2007), in northern Brazil go beyond mere games and leisure, revealing themselves in senses of religiosity. Party time, where everything is geared towards it, is composed of a set of relationships, being them: Relationships are interdependent at the time of the festival, and the interaction of these relationships is the force that moves this over historical time promoting the pertinence of the permanence or not of a specific party (Da Matta, 1997). Despite the tasks done by those who organize the festival, it is possible to seek the festival through the way that people organize and participate in certain party. Thus, it is not translated as a form of work, 
but in a time when everything is festive and around it, economic, political, artistic, cultural, religious relations are mixed.

According to Ferretti (2007), talking about the festival, it should seek to understand the meaning of organization and participation in the party, because this meaning is expressed as a duty and obligation, the festival reveals itself as human and social bonds linked to the dimension of religion. Da Matta (1997) and Bueno (2008) talk about how the parties mark expressions and elements of a community daily life that, when celebrating and commemorating, highlight its importance for the place. Then, festive spaces and party time can prove to be an event in which the culture of a group meets the culture of other groups that move through touristic means, it produce experiences and exalt aspects of daily life that it allows to reveal aspects of the production of religion in the party. At Marujada, this is explicit in the meaning of the term from the dances linked to the people related to experiences with navigation that in Amazon becomes emblematic for the role of its rivers and waters in the daily life of social groups, thus, it involves all body expressions that happen during the festival (Carvalho, 2010; Pinheiro,2017), in a relationship in which prayers and dances configure interchanged moments of acknowledgment and devotion, and not the mass or single player inside the Catholic Church.

However, visitors and tourists highlight the sociocultural aspects of Marujada as elements that influence the attraction or return and indication of the destination through the festival and culture (Pará, 2013). The dissemination and official treatment of Marujada festival, as inferred by Pará (2013) are limited and, itis restricted to present it as a component of the touristic calendar in Pará and articulated with aspects of the tradition of Catholicism and the Catholic Church; through what they describe as the sacred and profane party held in the Bragança city. In such way, in the context of touristic activity production, Marujada appears as Star Product, the most promising product, from the Atlantic Amazon Pole centralized in Bragança, that is being one of the most profitable products in this location and has the greatest possibility of capturing flows still restricted by the absence of more effective diffusion (Pará, 2014). As a tourist event, Bragança's Marujada party attends flows, mostly engendered by the Para's towns, which emphasis is in Belém city and something around $11 \%$ derived from the States of Minas Gerais, São Paulo and Maranhão, as an estimated permanence between 2 and 3 days, which illustrates an internal and non-consolidated tourism flow without expression related to other states.

The festival, Bragança's Marujada culminates in December from18th to 26thwith festive processes of praying and dancing original from the African culture made relevant in Pará by the resistance of enslaved black people in keeping traces of their religion and devotion to Saint Benedict. However, Bragança's Marujada corresponds to a whole space-socio and sociocultural movement in the northeast of Pará, based on a celebratory-ceremonial that prepares the culmination of the party: The Alms of Saint Benedict, which were constituted as caravans that traveled for over 200 years the region which was Bragança's territory with a delegation of "Marujos", that is a designation of men and women who lead the celebrations at Marujada festival, and musicians who sang and prayed carrying an image of Saint Benedict and collected donations for the party organization in December. The Alms have been responsible for providing other Marujada parties such as the one which is held in Tracuateua city where it is designated in the municipal touristic calendar (whose profile is based on cultural, folkloric, religious events) as party of Saint Sebastian and Saint Benedict, in this same calendar highlighted another festive event of Benedito's Marujada which is held in December in Vila Fátima (Pará, 2011).

In 1946, when this city was still a village administered by Bragança, the annual alms in Tracuateua did not happen because of the unavailability of transport for the conduction of sailors from Bragança, which led to the institutionalization in June of that year, of the Association of Tracuateua's Marujada of São Sebastião and São Benedito (AMSSSBT) which established the formation of 10 pairs of local sailors to replace those from Bragança. That same year in the city, it was decided to find a brotherhood inspired by the Bragantine, devoting itself to the Saint of Bragança's Marujada: Saint Benedict, and to the patron saint of Tracuateua city: Saint Sebastian. This led to Tracuateua's Marujada festival, which is held every year from January 18th to 21st. The instantiation of Tracuateua's festival reveals the expressiveness of dance and prayers that through the party express the local religion being common to hear people saying they are going to dance to Maruja$\mathrm{da}$; this phrase means that the person is going to acknowledge and celebrate some wish fulfilled thanks to intercession to the saint of protection and devotion. The instantiation of Marujada in Tracuateua shows the role and importance of the festival and the mediation through the intercession of the Saint to the local subjects, as shown in the following report:

"Marujada... for me it's already part of my life, got it? If I don't participate in it, it's the same as I don't... It's kind of stuck in my life, got it? And this is... When I started in Marujada, I entered because of... Paying a promise made by my mother..." (Verbal information). Thus, Marujada presents itself as a party linked to Catholicism and, according to Pinheiro (2017), reflects the Catholic influence present in the place without, however, restricting the doctrine of this religion with ceremonies and celebrations that we have systematized in 4 (four) great celebratory ceremonies. Inside the space- 
time of Marujada's festival, the days of the festival were from January 18th, which is destined to the preparation of the party, the last rehearsal of the dances, the raising of the Saints masts and the Matriz Square decoration and the Shack of the party, designated by the people who hold the party as Salon of the Saint.

The rehearsals are important because there is rigor in the movements, positions, and postures to be followed inside the Shack, especially in the dances when the new and old Sailors learn the steps and remember them. On the 19th and 20th of January, masses are held in the morning and right after the dances, meals, and prayers of thanks to the judges, which extend into the evening (around 10pm). On January 19th, there is the exaltation of Saint Benedict, considered the Saint of Marujada; on that day all decorations, ornaments and adornments must be in red with a Shack decorated in highlights in that color, emblems and insignia of Benedict, and the female sailors with red skirts and white shirts, and the male sailors all in white with red accents on their garments. On January 20th, there is the exaltation of Saint Sebastian, considered the city's patron saint. On that day, all decorations, ornaments, and adornments must be in blue, with the shack decorated in this color and Sebastian's emblems and insignia highlighted, and the female sailors with a blue skirt and white shirt and the male sailors in white pants and a colored blue shirt, which is the Saint Sebastian's colors. And on January 21 st, the festive season ends with "Préstito da Varrição" as the last day of celebration is called in analogy to the act of "sweeping", that is, removing all the ornaments that allude to the festival and the demolition of the Masts of the Saints, as shown in Table 01.

Table 1: The ceremonial celebrations of/in the festival of Tracuateua's Marujada

\begin{tabular}{|c|c|c|}
\hline CERIMONIAL/CELEBRATION & PLACE/TRAJECTORY & THE ACTIVITY \\
\hline FROM THE MASTS TO THE SAINTS & $\begin{array}{l}\text { Streets of the city-parting from } \\
\text { the houses of the party judges, } \\
\text { where the masts of St. Benedict } \\
\text { and St. Sebastian are ornamented } \\
\text { to city's central square, where the } \\
\text { main church and the shack of the } \\
\text { party are }\end{array}$ & $\begin{array}{l}\text { Pilgrimage carried out in a } \\
\text { simpleway, without procession } \\
\text { or prayers, starting at the } \\
\text { judge's house where the masts } \\
\text { are decorated with foliage and } \\
\text { fruits and ending in the central } \\
\text { square. }\end{array}$ \\
\hline
\end{tabular}

"During the week of the festival, the decoration of the party is done by the culture secretary. And, inside the shack e the masts are on the responsibility of the judges. There is the Saint Benedict's mast, and the judges are the ones who get and buy fruits, adorn and help to take it to the square" (Verbalinformation).

\section{JUDGES' PROCESSION}

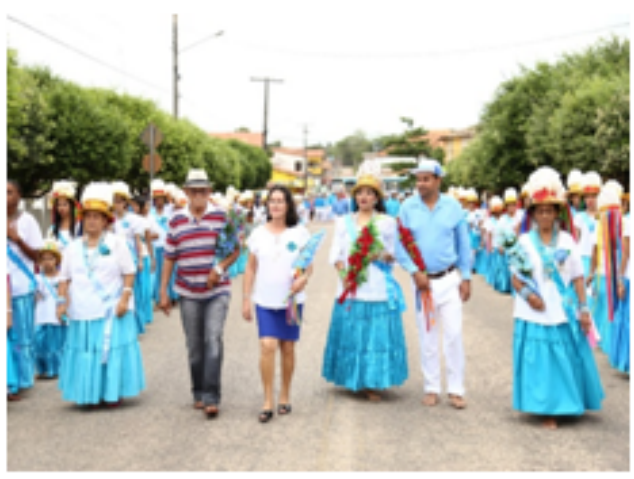

From the judges' house to the church. On the $1^{\text {st }}$ dayProcession of St. Benedict's judges. Mass at the local church with the image of St. Benedict on the altar.On the $2^{\text {nd }}$ dayProcession of St. Sebastian's judges. Mass at the local church with the image of St. Sebastian on th altar.
Procession carried out in all the mornings of party days os the streets of the city. Sailors seek the judges at their houses and drive them in clebration that involves dance during the procssion to the church, Where there is a mass celebrated by the local priest. 
DANCES, PRAYERS AND MEALS

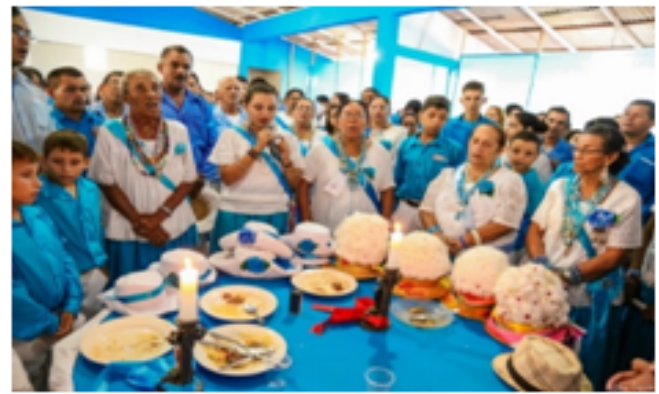

SWEEPING PROCESSION "Préstito da Varrição"

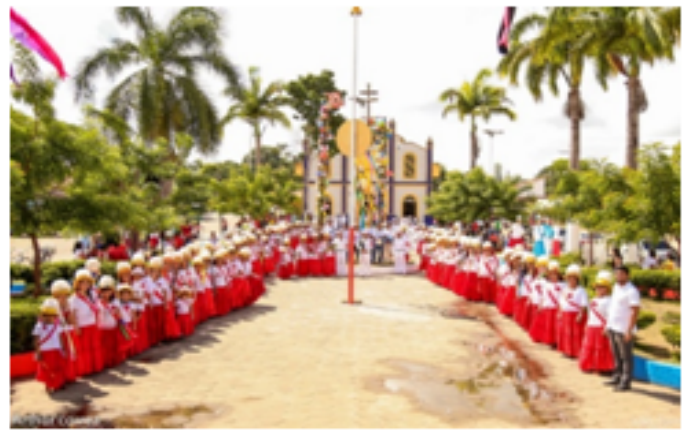

At the shack of the party. Inthe inner part, the center is destined to the sailors' dances, and the sideways to the tables on which are served the sailors' meals. In the outer side, there are stands destined to the audience.
Dances are performed on Ever day of the festival: the waltz, the mazurca, the retumbão, the xote, the carimbó, the chorado etc. It is the space Where the sailors' meals offered by the judges are also held, as well as the prayers in thanks to the saints.

The dance starts with the circle... Then when you finish dancing it here it goes, it's the rumble... here comes the "chorado "... comes the waltz that everybody dances. Then after the waltz comes the xote, then after that they will play anyone" (Verbal information)

At the Central Closing output of theparty with Square.Ornamented by the city sailors free to use any color of hall- Processions with dances the saint they wish to represent in the local square where the in the procession and dances local church, the Shack of the carried out in the square to Party and the Festive Masts are remove the masts and end the located. The sweeping would represent the cleaning of the space at the end of the festive time.

"We call the famous sweeping, which until a certain pointis danced with the clothes and after sweeping, anyone whohave a long skirt can participate" (Verbal information).

Source: The ceremonial celebrations of/in the festival of TracuateSource: Prepared from information found in field work carried out in Tracuateua in October2018. Photos: Arthur Dimas Corrêa de Oliveira (2018), kindly provided from his personal archive.

Table 1 shows what has been systematized (based on field descriptions) as celebratory ceremonies that, in "From the Masts to the Saints", emphasize the informality in the costumes of those who carry and transport the Saint Benedict and Saint Sebastian masts; in Judges' Procession with the order of the subjects formally dressed during the procession in the streets; in Dances, Prayers and Meals with emphasis on the internal side of the Shack with the dining table decorated in the color of the saint of the day; in the Sweeping Procession, with the female sailors in a row dressed formally in red for Benedito and blue for Sebastião, highlighting the specificity of the tall hats, covered with white flowers and with long ribbons in the same color as the skirt. In this context, it is noteworthy here that the choice between the colors of clothing is defined according to the predilections and personal devotion of Sailors. The spatial configuration of these celebratory ceremonies is circumscribed between the houses of the judges and the adjacencies to the Central Square, spreading out to the boundaries of the city and the area around the municipal gymnasium where there is a "cavalhada" (dispute among several men on horseback) on January 19th.

These highlights to Marujada's celebratory ceremonies, together with those described in table 01, point to a form-content of the festive similar to the Brazilian Festivities of the Divine with matrices of the various European flows of the Holy Spirit festivities and African flows of Devotion to Guides and Entities, that explicit in the composition of the ceremonials conductors: the judges, the Sailors compared to Butlers and emblematically in serving and sharing meals besides the performance of "cavalhada" and the sound of drums. In general, when looking at Table 1, the central square is the key to the Marujada festival, as it is in this space that all the festive flows happen; being it the reflection, the medium and the condition the establishment of the festive time, as it is there that the festival begins and ends with the raising and demolition of the Saints' Masts. This square centralizes daily activities where people usually meet to chat during the evenings, with 
bars, restaurants, a police station and the municipal library in its surroundings and, fundamentally, the Central Church and the Shack of Marujada, two central spatial objects to celebrate in Tracuateua and where the association's space is located, as the following report describes: "we have our own space, we have our own headquarters, that we've conquered for over eighteen years that we have this space which is right in front of the square, which is the association itself" (Verbal information).

From this point, the square plays an important role that goes beyond the festival, and for this reason, it is the celebratory place for the Marujada festival. It is also worth mentioning the role of the streets, which are easily accessible for being in the city center and it matters for the festival by composing themselves as a locus of the space-time transition of this activity in the city, being a transitional to the displacement of Sailors and people in general who accompany the party. It is while walking through the streets in procession or pilgrimage that the masts are exalted, that the sailors praise the judges of São Benedito (January 19th) and those of São Sebastião (January 20th) from their homes until the Mass inside the church and, still, the only procession of the party takes place in the afternoon: the General Procession, a different traditional procession that travels through the city in the afternoon on January 20th when "in the procession... the people go out on the street with the images of the patrons" (Verbal information) to carry out the "Sweeping" or cleaning of the festive space in the morning of the following day by removing all the ornaments that allude to the festivity.

\section{THE FESTIVITY, PARTICIPA- TION AND MEETING FOR THE PRACTICES OF THE PEOPLE OF- MAKING AT MARUJADA}

In the theoretical-analytical movements about party, the participation of all subjects is an essential category to the festive event; thus, everyone who is part of a commemoration, ceremony, celebration, etc. they transmute them into a party through participatory involvement in their space-time. According to Caillois (1988) and Amaral (1998), the party presupposes more than the simple presence of the crowds and imposes its movement, its mixture in an uninterrupted negotiation of multiple and diverse relationships in order to expand the number of its practitioners/goers, since, according to Amaral (1998, p. 85): "a party with little participation is not considered a good party".
Thus, the mixture through participation in the festive time-space corresponding to an element of the creative power of the encounter, delineates as a set of intersubjective relationships that the people constitute among themselves, their cultures, and their environments, and then affect the enunciation of the festive image. Therefore, when treating the party analytically, the mixture through participation invariably imposes the relational and the interactional between the festive environment or space-time and the party's people. In this way, there are people who prepare the celebration - the "makers" - and others who go to the party - the "visitors". It is noteworthy that event planners and other sectors involved need to understand the concept of the event to foster management actions that enable the optimization of positive aspects against the negative ones (Berselli \& Zucco, 2019, p. 52).

Thus, the "makers" mediate the participation and mixture as a practice of the people of making, in other words, those who engender and conduct the celebratory ceremonies in the festive space-time and those who wish in the intentionality of the sensitive, emotional, and sentimental, direct and communicate in the festivity the material and immaterial communion with its general environment whose strong integration between natural and cultural elements (Raffestin, 2009) projects its meanings. Hence, the choice of Marujada Hall as a shed, an architecture specialized in the local daily life through Flour houses, and hunting and fishing houses, places generally for collective use with local social groups, experiences, and sociability, as well as the choice of raising leaves and fruits on a mast and acknowledgment the abundance of food in the meals, as derived from the rural way in which the place is organized. Therefore, we see the evocation of the Shed as a locus of religion conducted by the "makers", the people of the festive practice as highlighted in the following excerpt of the account: "they pray a rosary, then they pray the litany, after this litany they sing the blessed, the blessed in their own "cabocla" language... they pray the blessed and offer it to the two patrons... something like this: 'The blessed and praised...'. Just like the church, the ritual is the same as the church" (Verbal information).

That way, there is a statement, an enunciation of what is said as "the same as in the church itself" and as "in their own cabocla language", that is, a displacement from the center of the church festivals to the party with the church in its surroundings. For this reason, during the Marujada party, after the mass, novenas take place before meals and after the dinner served to the Sailors in the Shed, the Prayer of Benedito to the Saints of the festival is recited, in a sung way, in gratitude for the meals. There are 7 (seven) subjects of festive practices in Tracuateua's Marujada: The President of AMSSSBT, the Judges, the Captain and Vice-Captain, "Capitoa" 
and Vice "Capitoa", Head of Line and Vice Head of Line, Sailors and Priests. Table 2 describes these subjects of making festival; the first two being more linked to the administrative organization of the party and the others to the organization and conduction of the celebratory ceremonies although all 7 (seven) subjects actively participate in the festival.

Table 2: The subjects (people) of the Marujada festival and their enunciations in Tracuateua-PA.

\begin{tabular}{|c|c|c|c|}
\hline SUBJECT & OF THE ASPECTS & OF THE MAKING & OF THE ENUNCIATIONS \\
\hline President & $\begin{array}{l}\text { Integrates the board of the } \\
\text { local association elected very } \\
\text { every two years to manage } \\
\text { and raise funds to the grga- } \\
\text { dizatioporathe festive event } \\
\text { with the associates, to the } \\
\text { city hall location, etc. }\end{array}$ & $\begin{array}{l}\text { Involved with maintenance } \\
\text { of the procession and the } \\
\text { party as an event, } \\
\text { hiring the musicians that } \\
\text { play the rhythms of Marujada } \\
\text { and articulating the city hall } \\
\text { ornamentation of the square. }\end{array}$ & $\begin{array}{l}\text { "The preparations are made, } \\
\text { like at least four, } \\
\text { five months earlier. We } \\
\text { start to mobilize, to look for } \\
\text { sponsorship... the partners } \\
\text { they only help us in } \\
\text { festive period" } \\
\text { (Verbal information). }\end{array}$ \\
\hline Judge & $\begin{array}{l}\text { Two pairs of judges, one } \\
\text { for each saint, trained } \\
\text { by people who } \\
\text { qualify for the position as } \\
\text { commitment of promise and } \\
\text { devotion to the chosen Saint } \\
\text { who are directly related to } \\
\text { the Capitain and Capitol. }\end{array}$ & $\begin{array}{l}\text { Take responsibility for the } \\
\text { financing and sponsoring } \\
\text { elements like: } \\
\text { ornamentation of the Masts } \\
\text { and of the Shack and the } \\
\text { confection of their garments. } \\
\text { They are at the frontline } \\
\text { of everyone's driving. }\end{array}$ & $\begin{array}{l}\text { "Since the rehearsals, each judge } \\
\text { judge is responsible for } \\
\text { everything. So, we must plan } \\
\text { in advance. And we end up, like, } \\
\text { starting since early, not to get } \\
\text { a last-minute thing, late, do } \\
\text { you understand?" } \\
\text { (Verbal information) }\end{array}$ \\
\hline $\begin{array}{l}\text { Capitain and } \\
\text { Vice capitain }\end{array}$ & $\begin{array}{l}\text { A pair that dresses and } \\
\text { attend to the doings of both } \\
\text { saints. It is considered a } \\
\text { prominent position. Lifetime } \\
\text { office passed on from father } \\
\text { to son, paying attention to } \\
\text { the props and clothes }\end{array}$ & $\begin{array}{l}\text { Organization to the } \\
\text { conduction of all celebratory- } \\
\text { ceremonies, keeping the } \\
\text { rows, positions, and clothing } \\
\text { of all men of making and } \\
\text { taking special care } \\
\text { with the dances in Maruiada. }\end{array}$ & $\begin{array}{l}\text { "The leader, on the day of the } \\
\text { presentation, God forbid, we're } \\
\text { keeping an eye out there, comes } \\
\text { right away with me and: "Look... } \\
\text { so-and-so's outfit, how is it } \\
\text { there." Then I send for him at } \\
\text { the secretary, and we'll talk" } \\
\text { (Verbal information) }\end{array}$ \\
\hline $\begin{array}{l}\text { Capitoa and } \\
\text { Vice Capitoa }\end{array}$ & $\begin{array}{l}\text { A pair that dresses and } \\
\text { attends to the doings of the } \\
\text { two saints. Considered a } \\
\text { prominent position. Lifetime } \\
\text { position transferred from } \\
\text { mother to daughter, having } \\
\text { freedom with jewelry, } \\
\text { clothing and } \\
\text { and props. }\end{array}$ & $\begin{array}{l}\text { Organization to the } \\
\text { conduction of all celebratory- } \\
\text { ceremonies, keeping the } \\
\text { rows, positions, and clothing of } \\
\text { all women of making and } \\
\text { taking special care to the } \\
\text { dances in Marujiadd }\end{array}$ & $\begin{array}{l}\text { "On the day of the party I } \\
\text { command the } \\
\text { ladies... we wear the wide skirt } \\
\text { on top, after that there's a tight- } \\
\text { fitting petticoat underneath so } \\
\text { the thigh doesn't show, right, } \\
\text { there's this one more." (Verbal } \\
\text { information). }\end{array}$ \\
\hline $\begin{array}{l}\text { Head of } \\
\text { line and Vice } \\
\text { Head of } \\
\text { Line }\end{array}$ & $\begin{array}{l}2 \text { pairs of women who } \\
\text { position ahead in the } \\
\text { two rows of sailors } \\
\text { during the ceremonies, in } \\
\text { space. It is considered } \\
\text { prominent position }\end{array}$ & $\begin{array}{l}\text { Help the Captain to } \\
\text { command, organize and take } \\
\text { care of the conduction in } \\
\text { ceremonies by the Sailors, in } \\
\text { special, make us } \\
\text { of the dances. }\end{array}$ & $\begin{array}{l}\text { "They Command the sailors. And } \\
\text { And the heads of line too, we } \\
\text { we are four, which is to take } \\
\text { the heads of line that we } \\
\text { go out on the streets, two go } \\
\text { from here and two from there". }\end{array}$ \\
\hline
\end{tabular}




\begin{tabular}{c|l|l|l}
\hline Sailors & $\begin{array}{l}\text { In unrestricted number since } \\
\text { since that integrated to the } \\
\text { local Marujada association. } \\
\text { Make up the conduction of } \\
\text { all celebratory ceremonies. }\end{array}$ & $\begin{array}{l}\text { Maintain and take care of } \\
\text { clothing and props. } \\
\text { They follow rehearsals and all } \\
\text { the ceremonials. Dance in } \\
\text { the beginning and end of } \\
\text { party. }\end{array}$ & $\begin{array}{l}\text { "I really like being a sailor, } \\
\text { very much. It's not just here that } \\
\text { we dance, wherever they call us, } \\
\text { if we can go, we'll go, if they } \\
\text { call." (Verbal Information). }\end{array}$ \\
\hline Priest & $\begin{array}{l}\text { The local parish priest. On } \\
\text { the first day, the central } \\
\text { church is adorned with color } \\
\text { and image of Benedita and } \\
\text { on the second day color and } \\
\text { image of Sebastiã̃a }\end{array}$ & $\begin{array}{l}\text { Holds masses in the } \\
\text { mornings during the days of } \\
\text { party with routine rituals being } \\
\text { a day for a saint and another } \\
\text { day for another one. }\end{array}$ & $\begin{array}{l}\text { "Religiosity, of black people, and } \\
\text { and there are the cultural } \\
\text { aspects, that for the priests, the } \\
\text { religious ones, they say it is the } \\
\text { profane side, but it isn't so } \\
\text { Profane... It's the cultural side } \\
\text { (Verbal Information) }\end{array}$ \\
\hline
\end{tabular}

Source: Prepared from information found in field work carried out in Tracuateua in October 2018.

Table 2 characterizes the subjects of festive making that make alive the tradition of their ancestors, that the introspection of this tradition is a result of experiences from the festival that internalize the space-time of the party and the sense of festival which is printed in the following excerpts from reports: "one of the things that I think is very beautiful and relevant at Marujada is the participation of people over eighty years old... And today we have more than..., almost one hundred and fifty young people who actively participate... And it makes the culture alive" (Verbal information). And still: "Then when mom got sick, right, then mom asked that she wanted me to be a sailor, to be the "capitoa", that she couldn't dance anymore. Then I said: - no mommy, take another female sailor, because there are some of them who are older than me... Then, mommy couldn't go, then there was no "capitoa", so they put me to be it" (Verbal information). These excerpts show the shine through the meaning of making festival by the subjects of the practice described in table 02 , with the judges of the party responsible for providing and financing the food, ornaments of the Masts, Shed and the fireworks used during the festival. In this context, it is an articulation between this subject of making and the President of the AMSSSBT for raise funds for the party infrastructure. In this way, the President of the AMSSSBT and the judges of the party hold meetings with everyone involved in the party to explain how the festivity will happen and the necessary amount to be paid by the sailors to cover the annual festival's expenses.

While the President is elected and stands out more in infrastructure planning, the judges are chosen from entries by people interested in this task from the list made available by the association and stand out for conducting the celebratory ceremonies and in the preparations and decorations of the party, being fundamental to the actions of the first day of the party and to the act of From the Masts to the Saints. And, despite this act of making festival being configured as a financial investment, the list of candidates to be judges of Marujada is big and don't stop growingand they are responsible for providing the food; thus, each of the Judges donates a meal during the festival, either lunch or dinner, some give a snack even if this is not mandatory. In this way, the Judges transit to the field of conductors of the festival who still count, in this more organizational configuration, with the captain and the vice-captain and with the "capitoa" and the "vicecapitoa", who are subjects with lifetime positions and responsible for maintaining the order of the festivity and of supervising the Sailors, who are subjects integrated into the festivity from the association in the AMSSSBT, being responsible for participating in all rehearsals and celebratory ceremonies and paying for, caring for and maintaining the traditions of making with: a) the procedures of barefoot pilgrimage and postures inside the Shack and; b) with the adaptations in the costumes and clothing: pants, shirt, hat for the male Sailors and skirt, sweatshirt, ornaments, jewelry and a Hat (the most expensive piece of clothing) for the female sailors.

In this context, if all subjects are responsible for paying for it and maintaining the standard of the garments made by local seamstresses to the Sailors, this constitutes presupposition to the participation in the party, especially at the time of the Dances, which configures most of the ceremonies. In general, most of the festive time takes place inside the Shed with the makers of the party interspersing prayers and dances in acknowledgement to the saints, the meals, and the judges of the party, remaining in prayer circles and litanies with danced movements and waltzes, xotes, rumbles, chorado and carimbó, mainly. Aspects of these dances can evince the colorful movement that goes from the party 
makers highlighted inred dresses on the day destined for Saint Benedict, to the same party makers dressed in blue on the day destined to Saint Sebastian. On this occasion, the role of the Heads of Line and Vice Headsof Line is highlighted, who assist in the maintenance, organization and arrangement of the pairs and circles of Marujada in the central area of the Shed, seeking to sustain order among the sailors in relation to the alignment of their lines so that they do not become disorganized (Figure 1).

Figure 1: From Benedito's red to Sebastião's blue.

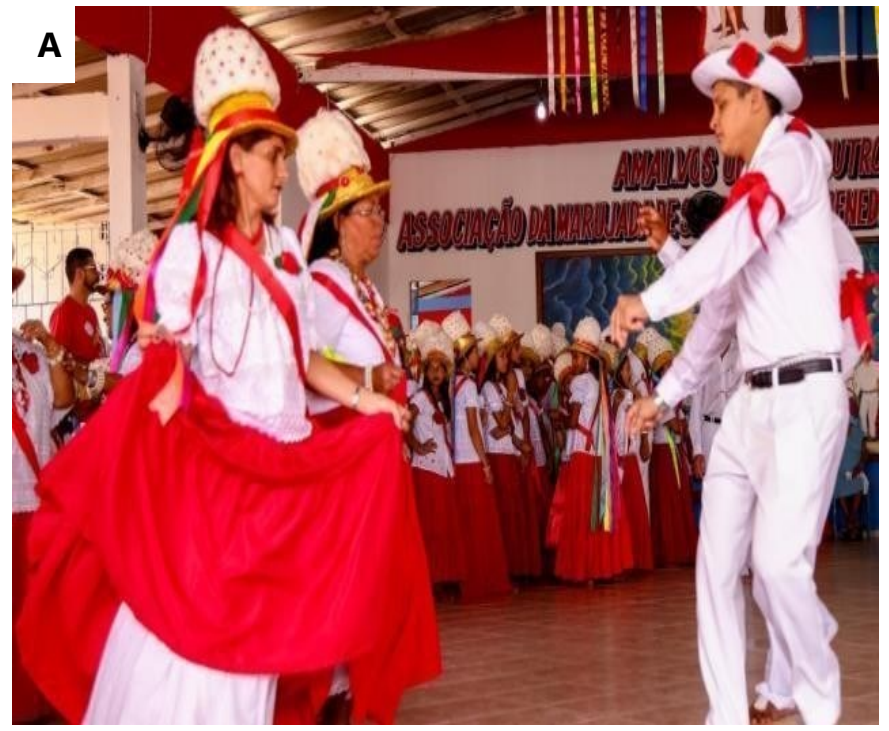

a) Sailors dancing to Saint Benedict dressed in red on January 19, 2018;

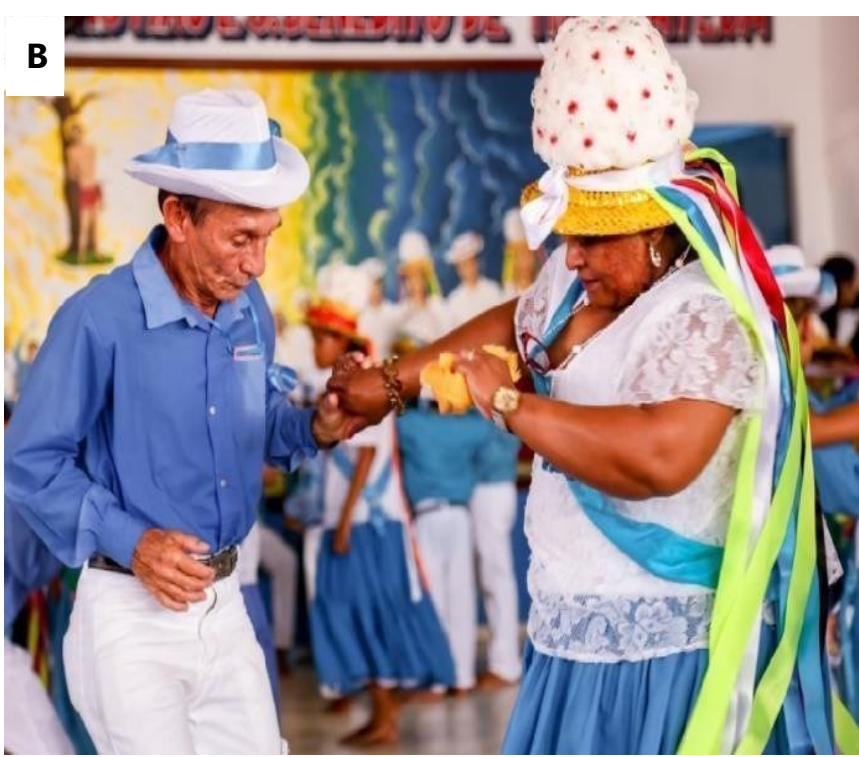

b) Sailors dancing to Saint Sebastian dressed in blue on January 20, 2018.

Source: Prepared from information found in field work carried out in Tracuateua in October 2018. Photos: Arthur Dimas Corrêa de Oliveira (2018), kindly provided from his personal archive.
In figure 1, the view of the Shed's interior defines by the color the space-time to which one saint the devotion is destined, starting from the day of the Saint ofMarujada to the day of the patron saint of the place, always having the dances initiated by the captain and "capitoa" who conduct them from the rehearsals before the festive season until the last day of the holiday. What makes to participate in the festival a unique moment for festive makers, as expressed in the following excerpt: "Oh, I think it's very beautiful, I really like being a sailor, very much" (Verbal information) also, in another excerpt: "It's a moment like this, which I say that are two very expected moments in the city: it's Círio and the Marujada. But I think that Marujadais even more... it's a very beautiful moment, very beautiful indeed, not only for those outside, but for who is inside, who dances, waits for this moment" (Verbal information). As stated in the previous report, Marujada is seen by those outside of the festival that is the participation in the space-time of the dance, also, is made by the frequency of the general public that needs to respect the rules and reverences when accessing the Shed which provides, for those who wanted to follow the celebratory ceremonies held there, a stand, which is highlighted in reports such as: "people from outside who come to watch Marujada... do you know where the Shed is? Yeah, we already think it's small for the number of people. Each year it gives more and more people" (Verbal information), as well as:"We always wait for this moment because it is a very beautiful moment, the city turns happy, right? We see that, even the touristic part, the city is really happy, the city is more agitated, right?!" (Verbal information).

The participation in the party is unrestricted, except for activities inside the Shed, in which only festive makers can stay by following all the rules and obligations with official dress, behavior and posture rules. In relation to celebratory ceremonies, the Sweeping Procession is the one that allows the public to participate more at the end of its conduction, essentially, in the dances that are performed, provided that they are wearing long skirts (women) and long pants (men), as highlighted in this report: "that until a certain point one dances with the clothes and after the sweeping, anyone with a long skirt can participate in that moment, which is also very cool because some people cannot dance for two, three days and end up dancing on the last day" (Verbal information). In such way, the Sweeping presents itself as the moment when: those from the place who were unable to participate in the conduction of the celebratory ceremonies, even due to the prices of the clothing and paraphernalia required for the ceremonial, as well as those external to the place (visitors and domestic tourists related to Bragantine people) who aim to celebrate from the insertion of the Marujada dances inside the Shed, which occurred soon after the demolition of the 
Saints Mastsin the end of the festive period on the last day of the Tracuateua's Marujada festival's program.

\section{FINAL CONSIDERATIONS}

Marujada is comprehended as a moment of leisure and participation whose duty and obligation to carry out denote aspects of festive religion in the Brazilian Amazon. Such aspects make its realization different from other events that have attractive proposals, since its festival, as a tradition, causes a rupture in everyday habits, presenting itself as a form of local culture and religion, in line with the perspectives of the "makers" in their preparations during the year. In this regard, the research context and the results presented in this article highlight the contact in the empirical process for further analyses, therefore, it gains importance for the perception process when talking about the festive "making", all its elaboration and the tourist attractiveness of theTracuateua'sMarujada (PA). In that view, this work points out the different ways that the mentioned subjects were approached about the festival and it is understood that the tourist attraction is also related to a cultural attached way to the subjects and to the way in which the process of construction of the celebration is reassembled every year.

The festive "makers" are willing to maintain tradition, religion, and faith. It was noticed that these subjects, each one with their own purpose, are the basis for attractiveness, especially when thinking about the perspectives of an inclusive tourism and mediator of experiences of meeting the others (worlds, lives, subjects, expressions). This is because it is in the Marujada festival and with that festival, which the perspectives of the Amazonian daily and religious world are revealed as a particularity of identifying processes of the subjects that from the space lived, they choose sociocultural elements which they want to dialogue with the outside worldand among the many possibilities as a tourist motivation.

Thus, the Marujada celebration and all its importance is found in the rooted cultural ensemble. Traditions bring to life the elements present, such as: dancing, prayers, clothing, acknowledgements, the variety of colors, food, the mast, sweeping and other elements of the party, which are attractive to tourism. However, the peculiarity of the Amazonian festival in the context of the northeast of Pará makes the Marujada be internally different and unique in this context. It is noteworthy that unlike other Marujadas in the State of Pará, Tracuateua's Marujada makes references to two Saints: Saint Benedict and Saint Sebastian, which can attract more visitors. Another very important point is that this Marujada is much more danced than a procession requiring the annual expansion of the Marujadahall in view of the growing demand.

Likewise, when analyzing the Marujada festival as a tourist event, it was noticed the need of obtaining statistical data to dimension the tourists and visitors flow uptake and what is the sociocultural effect that the event provides to the city's residents. However, based on data from Bragança, the Marujada festival was seen as an event capable of safeguarding the local culture.

Consequently, the participation of subjects in the festive making refers to a transmutation into a party by the participative involvement in their space-time. Providing multiple and diverse relationships that allow to expand the number of practitioners and frequenters. It is estimated that the inclusion of Tracuateua's Marujada Festival in the state events calendar will promote an increase in the touristic flows of the event. By elevating the festival to a more relevant dimension for tourist attractiveness, from the projection of the specificities of the local culture; thus, as occurred with Bragança's Marujada Festival, which receives municipal and regional flows.

\section{REFERENCES}

Amaral, R. (1998). Festa à brasileira: significados do festejar, no país que "não é série". Tese (Doutorado em Antropologia) pela Universidade de São Paulo.

Bahl, M. (2004). Viagens e roteiros turísticos. Curitiba-PR: Protexto.

Berselli, C., \& Zucco, F. D. (2019). A imagem da Festa Nacional do Doce - Fenadoce em Pelotas (RS), Brasil, perante a percepção dos residentes. Applied Tourism, 4 (1), 41 56 .

Bueno, M. (2008). Lazer, festa e festejar. Revista de Cultura e Turismo (CULTUR), 2 (2), 1-18.

Caillois, R. (1988). O homem e o sagrado. Lisboa: Edições 70.

Carvalho, G. (2010). A festa do "Santo Preto": tradição e percepção da Marujada Bragantina. Dissertação (Mestrado Desenvolvimento Sustentável) pela Universidade de Brasília.

Claval, P. (2011). A festa e a cidade. Revista Cidades, Grupos de Estudos Urbanos, Presidente Prudente, 8 (13), 27 44.

Da Matta, R. (1997). Carnavais, malandros e heróis: para uma sociologia do dilema brasileiro. 6. ed. Rio de Janeiro: Rocco.

Deslandes, S. (1994). A Construção do projeto de Pesquisa. Pesquisa Social: teoria, método e criatividade. 31-49. Petrópolis, RJ: Vozes, 1994.

Espeso-Molinero, P. (2019). Tendencias del turismo cultural. Revista de Turismo y Patrimônio Cultural, 17 (6), 1101 1112.

Ferretti, S. (2007). Religião e Culturas Populares. In: XIV Jornadas sobre Alternativas Religiosas en América Latina. Acesso em 15 jan. 2020. Dis- 
ponível em www.gpmina.ufma.br/pastas/doc/ Religião/FestasPopulares.Pdf.

Filippim, M. L.; Bahl, M. (2017). Experiências de ressignificação de tradições carnavalescas em Podence e ovar Portugal. Caderno Virtual de Turismo. 17 (1), 155-170.

Gomes, R. (1994). A análise de dados em pesquisa qualitativa. In: Minayo, M. C. Pesquisa Social: teoria, método e criatividade. 67-79. Petrópolis, RJ: Vozes.

Minayo, M. C. (2002). Pesquisa Social: teoria, método e criatividade. Petrópolis, RJ: Vozes.

Pará. Secretaria de Estado de Turismo do Pará. (2011). Plano Ver o Pará: plano estratégico de turismo do estado do Pará. Belém. Acesso em 16 de jan. de 2020. Disponível em http://www.setur.pa.gov.br/plano-ver-o-para.

Pará. Secretaria de Estado de Turismo do Pará. (2013). Pesquisa de Demanda Turística do Festival da Marujada, Bragança-PA. Acesso em 10 fev. 2020. Disponível em http://setur.pa.gov.br/sites/default/files/pdf/ pesquisa_de_demanda_turistica_do_fest ival da_marujada_2013.pdf

Pará. Secretaria de Estado de Turismo do Pará. (2014). Inventário da Oferta Turística de Tracuateua. Acesso em 10 fev. 2020. Disponível em http://www.setur.pa.gov.br/si _2013final.pdf sefault/files/pdf/inventario tracuateua_

Pinheiro, A. J. (2017). Síntese histórica de Tracuateua. Belém: Ed. do Autor.

Raffestin, C. A. (2009). Produção das estruturas territoriais e sua representação. In: Şaquet, M., \& Sposito, E. (Org.). Territórios e territorialidades: teorias, processos e conflitos. São Paulo: Expressão Popular.

Santos, M. (1999). A natureza do espaço: espaço e técnica, razão e emoção. São Paulo: Hucitec.

Cruz Neto, O. (1994). O trabalho de campo como descoberta e criação. Pesquisa Social: teoria, método e criatividade. 51-66. Petrópolis, RJ: Vozes.

Soja, E. W. (1993). Geografias pós-modernas a reafirmação do espaço na teoria social crítica. Tradução de Vera Ribeiro. Rio de Janeiro: Zahar.

Sollerio, A. A. A., \& García, O. M. (2020). La producción del espacio social en Playa del Carmen,Quintana Roo, México. Espacialidad, Socialidad e Historicidade RBTUR, São Paulo, 14 (2), 95-122.

Wagner, R. (1981). The Invention of Culture. Chicago: The University of Chicago Press. 